Erratum

\title{
Erratum: Farber, R.; Rosenberg, A.; Rozenfeld, S.; Banet, G.; Cahan, R. Bioremediation of Artificial Diesel-Contaminated Soil Using Bacterial Consortium Immobilized to Plasma-Pretreated Wood Waste. Microorganisms 2019, 7, 497
}

\author{
Ravit Farber ${ }^{1}$, Alona Rosenberg ${ }^{1}$, Shmuel Rozenfeld ${ }^{1}$ (D), Gabi Banet ${ }^{2}$ and Rivka Cahan ${ }^{1, *}$ \\ 1 Department of Chemical Engineering and Biotechnology, Ariel University, Ariel 40700, \\ Israel; ravitf@ariel.ac.il (R.F.); alonar@ariel.ac.il (A.R.); shmuelro@ariel.ac.il (S.R.) \\ 2 Dead Sea-Arava Science Center, Arava 86910, Israel; gabib@adssc.org \\ * Correspondence: rivkac@ariel.ac.il; Tel.: +972-54-7740293
}

Received: 6 December 2019; Accepted: 10 December 2019; Published: 10 December 2019

The authors wish to make the following erratum in this paper [1].

There is a mistake in the spelling of the fourth author's name:

Ravit Farber ${ }^{1}$, Alona Rosenberg ${ }^{1}$, Shmuel Rozenfeld ${ }^{1}$, Gabi Benet ${ }^{2}$ and Rivka Cahan ${ }^{1, *}$ the corrected spelling should be:

Ravit Farber ${ }^{1}$, Alona Rosenberg ${ }^{1}$, Shmuel Rozenfeld ${ }^{1}$, Gabi Banet ${ }^{2}$ and Rivka Cahan ${ }^{1, *}$

The authors apologize for any inconvenience this may have caused.

Conflicts of Interest: The authors declare no conflict of interest.

\section{References}

1. Farber, R.; Rosenberg, A.; Rozenfeld, S.; Banet, G.; Cahan, R. Bioremediation of Artificial Diesel-Contaminated Soil Using Bacterial Consortium Immobilized to Plasma-Pretreated Wood Waste. Microorganisms 2019, 7, 497. [CrossRef] [PubMed]

(C) 2019 by the authors. Licensee MDPI, Basel, Switzerland. This article is an open access article distributed under the terms and conditions of the Creative Commons Attribution (CC BY) license (http://creativecommons.org/licenses/by/4.0/). 